\title{
Genetic characterization of the non-structural protein-3 gene of bluetongue virus serotype-2 isolate from India
}

\author{
Raghavendra Sumanth Pudupakam ${ }^{1}$, Shobana Raghunath², Meghanath Pudupakam³ and \\ Sreenivasulu Daggupati ${ }^{1}$
}

1. Department of Veterinary Microbiology, College of Veterinary Science, Sri Venkateswara Veterinary University, Tirupati, Andhra Pradesh, India; 2. Department of Biomedical Sciences and Pathobiology, Virginia Polytechnic Institute and State University, Blacksburg, Virginia, USA; 3. Department of Biochemistry, Osmania University, Hyderabad, Telangana, India.

Corresponding author: Raghavendra Sumanth Pudupakam, e-mail: prsumanth@gmail.com,

Co-authors: SR: shobana.feb2000@gmail.com, MP: prmeghanath@gmail.com, SD: dsreenivasulu10@gmail.com Received: 27-11-2016, Accepted: 23-02-2017, Published online: 23-03-2017

doi: 10.14202/vetworld.2017.348-352 How to cite this article: Pudupakam RS, Raghunath S, Pudupakam M, Daggupati S (2017) Genetic characterization of the non-structural protein-3 gene of bluetongue virus serotype-2 isolate from India, Veterinary World, 10(3): 348-352.

\begin{abstract}
Aim: Sequence analysis and phylogenetic studies based on non-structural protein-3 (NS3) gene are important in understanding the evolution and epidemiology of bluetongue virus (BTV). This study was aimed at characterizing the NS3 gene sequence of Indian BTV serotype-2 (BTV2) to elucidate its genetic relationship to global BTV isolates.
\end{abstract}

Materials and Methods: The NS3 gene of BTV2 was amplified from infected BHK-21 cell cultures, cloned and subjected to sequence analysis. The generated NS3 gene sequence was compared with the corresponding sequences of different BTV serotypes across the world, and a phylogenetic relationship was established.

Results: The NS3 gene of BTV2 showed moderate levels of variability in comparison to different BTV serotypes, with nucleotide sequence identities ranging from $81 \%$ to $98 \%$. The region showed high sequence homology of $93-99 \%$ at amino acid level with various BTV serotypes. The PPXY/PTAP late domain motifs, glycosylation sites, hydrophobic domains, and the amino acid residues critical for virus-host interactions were conserved in NS3 protein. Phylogenetic analysis revealed that BTV isolates segregate into four topotypes and that the Indian BTV2 in subclade IA is closely related to Asian and Australian origin strains.

Conclusion: Analysis of the NS3 gene indicated that Indian BTV2 isolate is closely related to strains from Asia and Australia, suggesting a common origin of infection. Although the pattern of evolution of BTV2 isolate is different from other global isolates, the deduced amino acid sequence of NS3 protein demonstrated high molecular stability.

Keywords: bluetongue virus, non-structural protein-3 gene, phylogenetic analysis.

\section{Introduction}

Bluetongue is an infectious, non-contagious, arthropod-borne viral disease of ruminants caused by bluetongue virus (BTV), an archetypal member of the Orbivirus genus in the family Reoviridae. The disease causes substantial economic losses to livestock industry worldwide. In addition, there are mandatory restrictions on the movement of ruminants and other animal products from BTV endemic countries to BTV free countries as it is listed under "List A" diseases by Office Internationale des Epizooties [1]. BTV is architecturally complex and its genome is composed of 10 discrete segments of double-stranded RNA of approximately 19,200 base pairs in length [2,3]. Virus particle is approximately $90 \mathrm{~nm}$ in diameter comprising a three-layered icosahedral capsid protein [4,5]. Viral genome encodes for seven structural (VP1 through to

Copyright: Pudupakam, et al. Open Access. This article is distributed under the terms of the Creative Commons Attribution 4.0 International License (http://creativecommons.org/licenses/ by/4.0/), which permits unrestricted use, distribution, and reproduction in any medium, provided you give appropriate credit to the original author(s) and the source, provide a link to the Creative Commons license, and indicate if changes were made. The Creative Commons Public Domain Dedication waiver (http:// creativecommons.org/publicdomain/zero/1.0/) applies to the data made available in this article, unless otherwise stated.
VP7) and four non-structural (NS1 through to NS4) proteins $[6,7]$.

At present, 27 BTV serotypes have been reported worldwide [8,9]. Of these, 13 BTV serotypes (Serotypes-1, 2, 3, 4, 6, 9, 10, 12, 16, 17, 18, 21 and 23) were isolated in India $[9,10]$. The occurrence of new serotypes suggests regular incursions of BTV into India. Global climatic changes and activity of transmission vectors resulted in intercontinental spread of BTV. As a result, significant evolutionary diversity was observed among field strains [11]. Reassortment, genetic drift, and shift were identified as the key factors responsible for the evolution of new BTV serotypes [12]. It is essential to investigate the geographical origin of novel BTVs for a better understanding of their incursions into enzootic foci. This can be achieved by comparative analysis of non-structural protein-3 (NS3) gene [13]. Although isolation and serological characterization of BTV serotype-2 (BTV2) Indian isolate has been reported [14], genetic analysis of NS3 gene and its phylogenetic relationship to global isolates has not been reported so far.

To characterize the NS3 gene of Indian BTV2 isolate, nucleotide and amino acid sequences were analyzed in comparison with those of strains 
representative of different geographical regions worldwide. Phylogenetic relationship of BTV2 to global isolates has been established.

\section{Materials and Methods \\ Ethical approval}

The experiments comply with guidelines laid down by the Institutional Ethical Committee.

\section{Propagation of virus}

BTV2 maintained at the Department of Microbiology, College of Veterinary Science, Tirupati at $2^{\text {nd }}$ passage level, was cultivated in BHK-21 cell line using Glassgow's Modified Eagles Medium containing 5\% fetal calf serum.

\section{Amplification and cloning of BTV NS3 gene}

The identification of the virus was confirmed by amplifying a 762 bp region (20 to 781nt) of the conserved region of S10 (NS3) gene of the virus using reverse transcriptase polymerase chain reaction. Trizol method of RNA extraction was used to extract total RNA from infected cells from $25 \mathrm{~cm}^{2}$ tissue culture bottle when the cytopathic effect was about $75 \%$. Primers, NS3L-GCGGGATCCATGCTATCCGGGCTGAT and NS3R-GGCAAGCTTCCCCGTTAGACAGCAGT were used to reverse transcribe and amplify NS3 gene. The reverse transcription was carried out by the addition of five units of avian myeloblastosis virus reverse transcriptase enzyme (Bangalore Genei Pvt. Ltd.). The synthesized cDNA was used to amplify the NS3 gene of BTV by polymerase chain reaction with initial denaturation at $94^{\circ} \mathrm{C}$ for $3 \mathrm{~min}$, followed by 30 cycles of $1 \mathrm{~min}$ denaturation at $94^{\circ} \mathrm{C}, 1 \mathrm{~min}$ primer annealing at $58^{\circ} \mathrm{C}$ and $2 \mathrm{~min}$ primer extension at $72^{\circ} \mathrm{C}$. The final primer extension was kept at $72^{\circ} \mathrm{C}$ for $10 \mathrm{~min}$.

The purified NS3 gene product was cloned in pTZ57 R/T cloning vector (Fermentas USA). The recombinant plasmid DNA was transformed into calcium chloride treated DH5 $\alpha$ (Escherichia coli) competent cells and plated on Luria-Bertani agar medium. The recombinant clones were selected initially by blue-white screening. The selected clones were further confirmed by restriction enzyme digestion analysis and sequencing methods. For sequencing, three clones were selected from several recombinant clones. Sequencing was done in both directions using T7 and M13 primers for all the clones to generate a contiguous sequence using automated DNA sequencer (ABI Perkin Elmer). The sequence has been submitted to NCBI (GenBank) with accessions number KX650180.

\section{Sequence and phylogenetic analysis}

The coding region (690 bp) of NS3 gene was subjected to sequence analysis and compared with different serotypes across the globe. The sequence analysis was performed after converting into FASTA format on internet (website: http://www-ncbi-nlmnih-gov.ezproxy.lib.vt.edu). Multiple alignments of nucleotide and deduced amino acid sequences were done using CLUSTAL W program. Both percent nucleotide identity and amino acid residue substitutions were studied on comparison with those of different BTV serotypes and isolates of BTV2 from various geographical regions.

The phylogenetic tree was inferred using the neighbor-joining method in MEGA7 (20). The following convention was used to identify nucleotide sequences - BT_serotype number_three-letter country code last three digits of sequence accession number as listed in Table-1. The S10 gene sequence of epizootic hemorrhagic disease virus serotype 1 was used as the outgroup to root the trees. The percentage of replicate trees in which the associated taxa clustered together in the bootstrap test (500 replicates) are shown next to the branches. The evolutionary distances were computed using the maximum composite likelihood method and are in the units of the number of base substitutions per site. The analysis involved 46 nucleotide sequences.

\section{Results and Discussion}

Sequence analysis of the NS3 gene revealed a coding region of $690 \mathrm{bp}$ with two in-frame AUG codons. Upon alignment of nucleotide sequences, the region showed nucleotide sequence identities of 81-84\% with North American (USA), 82-85\% with Central American and Caribbean (Honduras, Costa Rica, Dominican Republic, Puerto Rico and Jamaica), and $83 \%$ with African and Mediterranean isolates (South Africa, Greece, Israel, France, and Italy). Despite their geographically distant origins, a high sequence homology of $90-96 \%$ was observed with Asian and Australian isolates. The nucleotide similarity shared with Asian and Australian strains support the hypothesis of a common origin of infection while the sequence variability observed with other BTV isolates demonstrated viral evolution over a period. As expected, a high rate of sequence identity (95-98\%) was observed with BTV serotypes from the Indian sub-continent. The nucleotide substitutions may reflect the intrinsic rate of viral mutation (lack of proofreading activity of viral RNA-dependent RNA polymerase) or are the result of viral selection influenced by different vectors and hosts as previously demonstrated [15].

Despite the host-geographic connection of sequence variability, amino acid sequence (229 aa) analysis demonstrated the stability of NS3 protein in the BTV2 strain circulating in India. The region showed high sequence homology of $93-99 \%$ at amino acid level with various BTV serotypes. We found that PPXY/PTAP late domain motifs, glycosylation sites (63-65aa and 150-152aa), the two hydrophobic domains (119-133aa and 167-183aa), the cysteine (C) residues at amino acid positions 137 and 181, and a tryptophan residue (W) at position 159 were conserved in NS3 protein (Figure-1). The nucleotide substitutions in the NS3 gene coding region were generally silent or conservative in deduced amino acid 
Table-1: BTV isolates subjected to sequence analysis.

\begin{tabular}{|c|c|c|c|}
\hline Country & Serotype & $\begin{array}{c}\text { Accession } \\
\text { number }\end{array}$ & ID \\
\hline \multicolumn{4}{|l|}{ North America } \\
\hline USA & 10 & AF044385 & BT10USA385 \\
\hline USA & 11 & AF044704 & BT11USA704 \\
\hline USA & 13 & AF044710 & BT13USA710 \\
\hline USA & 17 & AF044709 & BT17USA709 \\
\hline \multicolumn{4}{|c|}{$\begin{array}{l}\text { Central America and } \\
\text { Caribbean Basin }\end{array}$} \\
\hline Honduras & 1 & AY426598 & BT1HND598 \\
\hline Costa Rica & 3 & AY426599 & BT3CRI599 \\
\hline Dominican & 4 & AY426602 & BT4DOM602 \\
\hline \multicolumn{4}{|l|}{ Republic } \\
\hline Honduras & 6 & AY426603 & BT6HND603 \\
\hline Dominican & 8 & AY426604 & BT8DOM604 \\
\hline \multicolumn{4}{|l|}{ Republic } \\
\hline Jamaica & 12 & AY426595 & ВT12JAM595 \\
\hline Puerto Rica & 17 & AY426596 & BT17PRI596 \\
\hline \multicolumn{4}{|l|}{ Africa and } \\
\hline \multicolumn{4}{|l|}{ Mediterranean } \\
\hline \multicolumn{4}{|l|}{ Basin } \\
\hline South Africa & 1 & AF512911 & BT1ZAF911 \\
\hline South Africa & 2 & AF512920 & BT2ZAF920 \\
\hline Greece & 1 & AY677628 & BT1GRC628 \\
\hline France & 2 & AF481093 & BT2FRA093 \\
\hline Italy & 2 & AY823222 & BT2ITA222 \\
\hline South Africa & 3 & AF512906 & BT3ZAF906 \\
\hline Greece & 4 & AY691692 & BT4GRC692 \\
\hline Israel & 4 & AY775158 & BT4ISR158 \\
\hline Italy & 4 & AY775156 & BT4ITA156 \\
\hline South Africa & 8 & AY120938 & BT8ZAF938 \\
\hline Greece & 9 & AY449651 & BT9GRC651 \\
\hline Italy & 9 & AY775161 & ВT9ITA161 \\
\hline South Africa & 11 & AF512921 & BT11ZAF921 \\
\hline South Africa & 18 & AF512915 & BT18ZAF915 \\
\hline \multicolumn{4}{|c|}{ Asia and Australia } \\
\hline Indonesia & 1 & AF529049 & BT1IDN049 \\
\hline Australia & 2 & AF529057 & BT1AUS057 \\
\hline China & 3 & AF135224 & BT2CHN224 \\
\hline Indonesia & 4 & AF529050 & BT3IDN050 \\
\hline China & 4 & AF135225 & ВT3CHN225 \\
\hline China & 5 & AF135226 & BT4CHN226 \\
\hline China & 12 & AF135227 & BT12CHN227 \\
\hline China & 16 & AF135229 & BT16CHN229 \\
\hline Australia & 20 & AF529055 & BT20AUS055 \\
\hline Australia & 21 & AF529058 & BT21AUS058 \\
\hline Indonesia & 23 & AF529051 & BT23IDN051 \\
\hline India & 12 & KC662621 & BT12IND621 \\
\hline India & 9 & KP696660 & BT9IND660 \\
\hline India & 23 & EU131022 & BT23IND022 \\
\hline India & 1 & KP696581 & BT1IND581 \\
\hline India & 16 & KX302643 & BT16IND643 \\
\hline India & 4 & KF560426 & BT4IND426 \\
\hline India & 3 & JQ771822 & BT3IND822 \\
\hline India & 18 & EU131025 & BT18IND025 \\
\hline India & 2 & KX650180 & BT2IND180 \\
\hline $\begin{array}{l}\text { Epizootic } \\
\text { hemorrhag }\end{array}$ & 1 & NC_013405 & EHD1USA405 \\
\hline
\end{tabular}

The 46 BTV serotypes, including the epizootic hemorrhagic disease virus serotype 1 analyzed in the study were listed in the table. The following convention was used to identify nucleotide sequence-BT_serotype number_three-letter country code last three digits of sequence accession number. $\mathrm{BTV}=$ Bluetongue virus

sequences, thus not affecting the protein structure. The likely explanation is in the key role of the protein in viral maturation and egress [7]. Furthermore, we found unique amino acid substitutions of isoleucine for methionine at position 122 and glycine for serine at position 162 in this highly conserved protein. The NS3 protein is non-essential for viral replication [16]; thus, nonsynonymous mutation in its gene could be less restrictive. However, the protein seems to be involved in the inhibition of interferon synthesis as well as in the ability of the virus to overcome the host immune response [17]. It would be interesting to understand the effect of these changes on the infectivity of BTV.

Computation of evolutionary distances among global BTV serotypes by maximum likelihood method resulted in recovery of two major Clades, I and II (Figure-2). Within these broad clades, four subclades (Ia, Ib, IIa, and IIb) or topotypes have been identified that were associated with respective geographical regions. These observations on the geographical distribution of BTVs are in agreement with previously defined topotypes [18]. The existence of distinct topotypes within individual BTV serotypes indicate significant geographically independent evolution of this segment. Geographically diverse group of isolates representing Central America (Dominican Republic and Puerto Rico), Mediterranean Basin (Greece, Italy, Israel and France) and South Africa were included in subclade Ib. Subclade IIa includes isolates from Mediterranean Basin (Italy), Caribbean (Jamaica), and South Africa. BTV isolates from the USA segregated in subclade IIb along with viruses from Central America (Costa Rica and Honduras). Recent BTV isolates from Greece (BT1GRC628 and BT9GRC651) and Italy (BT9ITA161) shared a closer relationship with Asian strains. Our observations support the earlier reports of Asian origin of recent European isolates as a result of recent climatic changes and the activity of Culicoides vector [19]. The BTV2 virus (BT2IND180) from India closely clustered with isolates of Asia (India, China, and Indonesia) and Australia in Subclade Ia. Phylogenetic clustering within subclade Ia suggested the exotic status of this serotype in India and its origin from Asia and Australia.

\section{Conclusion}

Genetic characterization of circulating strains remains essential to understand whether the virus is evolving and to draw up surveillance and prevention strategies. In this study, NS3 gene of Indian BTV2 isolate was sequenced and analyzed in comparison with BTV sequences worldwide. Phylogenetic network analysis of $46 \mathrm{BTV}$ sequences revealed four topotypes irrespective of their serotype. The NS3 gene sequence-based clustering indicated that the Indian BTV2 isolate is closely related to strains from Asia and Australia, representing a single virus lineage. Although the pattern of evolution of BTV2 isolate is different from other Indian BTV serotypes and global isolates, NS3 gene sequence and functional motifs are highly conserved. 


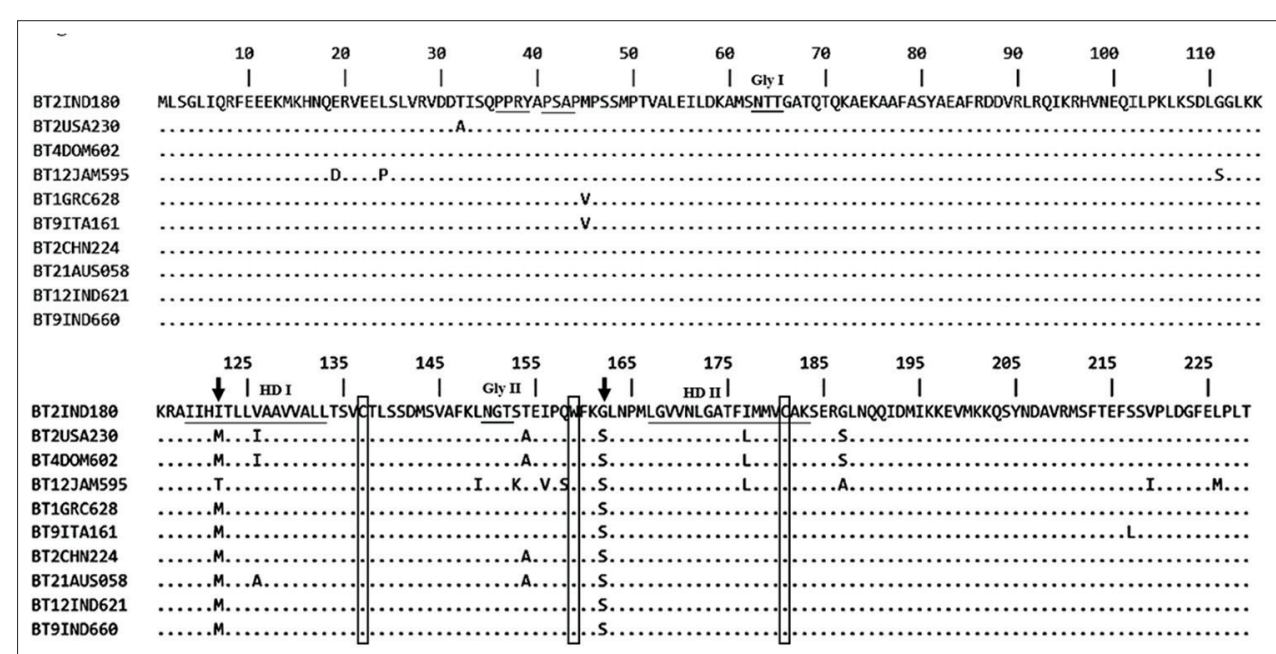

Figure-1: Alignment of the amino acid sequences of bluetongue virus (BTV) non-structural protein-3 (NS3) protein. Alignment of the deduced amino acid sequences (229 aa) of BTV NS3 protein. The late motif domains PPXY/PSAP, glycosylation sites (Gly I and Gly II) and hydrophobic domains (HD I and HD II) have been underlined. The unique amino acid substitutions isoleucine (I) and glycine (G) were indicated by an arrow. The conserved residues cysteine (C) and tryptophan (W) are indicated within a box.

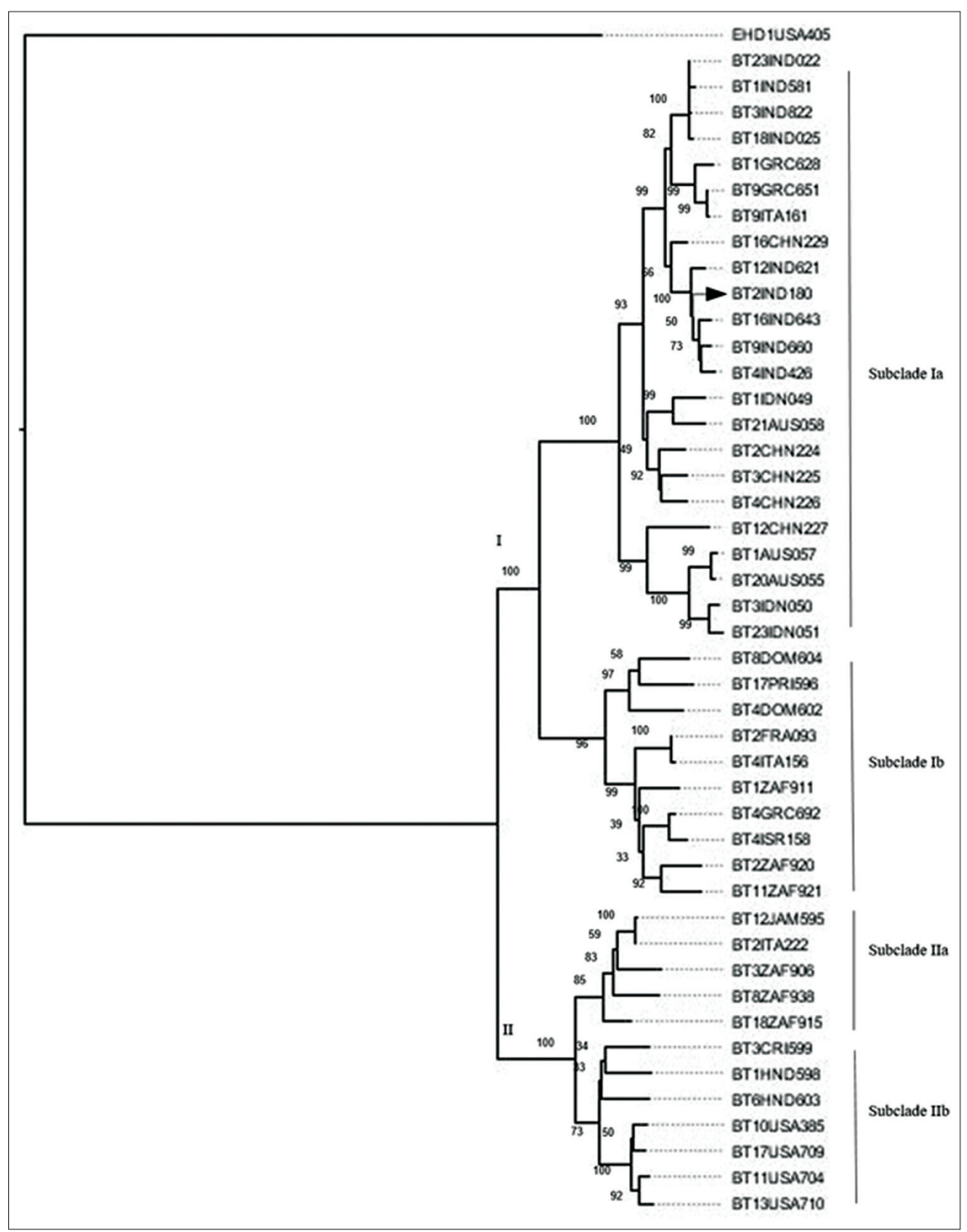

Figure-2: Phylogenetic tree of the non-structural protein-3 nucleotide coding sequences of different bluetongue virus (BTV) isolates of the world. The evolutionary history was inferred using the neighbor-joining method using MEGA7 with bootstrap values of 500 replicates. Different lineages and sub-lineages are indicated. Our isolate, Indian BTV serotype-2 is indicated by a triangle. 


\section{Authors' Contributions}

SD was the project leader. RSP and SD were responsible for experimental and project design. RSP performed most of the experiments. SR was involved in sequence analysis. MP made conceptual contributions. All authors participated in writing the manuscript and approved it for submission.

\section{Acknowledgments}

Authors wish to thank (i) Associate Dean, College of Veterinary Science, Tirupati, Andhra Pradesh, India (ii) Dr. S. M. Byregowda, Institute of Animal Health and Veterinary Biologicals, Bengaluru, Karnataka, India and (iii) Dr. V. V. S. Suryanarayana, Indian Veterinary Research Institute, Bengaluru, Karnataka, India, for providing the technical help and facilities to do the work. This research did not receive any specific grant from funding agencies in the public, commercial, or not-for-profit sectors.

\section{Competing Interests}

The authors declare that they have no competing interests.

\section{References}

1. Health WOFA. (2011) OIE Listed Diseases 2011. OIE, Paris.

2. Schwartz-Cornil, I., Mertens, P.P., Contreras, V., Hemati, B., Pascale, F., Breard, E., Mellor, P.S., MacLachlan, N.J. and Zientara, S. (2008) Bluetongue virus: Virology, pathogenesis and immunity. Vet Res., 39: 46.

3. Ratinier, M., Caporale, M., Golder, M., Franzoni, G., Allan, K., Nunes, S.F., Armezzani, A., Bayoumy, A., Rixon, F., Shaw, A. and Palmarini, M. (2011) Identification and characterization of a novel non-structural protein of bluetongue virus. PLoS Pathog., 7: e1002477.

4. Grimes, J.M., Burroughs, J.N., Gouet, P., Diprose, J.M., Malby, R., Zientara, S., Mertens, P.P. and Stuart, D.I. (1998) The atomic structure of the bluetongue virus core. Nature, 395: 470-478

5. Roy, P. (2008) Functional mapping of bluetongue virus proteins and their interactions with host proteins during virus replication. Cell Biochem. Biophys., 50: 143-157.

6. Coetzee, P., Stokstad, M., Venter, E.H., Myrmel, M. and Van Vuuren, M. (2012) Bluetongue: A historical and epidemiological perspective with the emphasis on South Africa. Virol. J., 9: 198.

7. Mohl, B.P. and Roy, P. (2014) Bluetongue virus capsid assembly and maturation. Viruses, 6: 3250-3270.

8. Zientara, S., Sailleau, C., Viarouge, C., Hoper, D., Beer, M., Jenckel, M., Hoffmann, B., Romey, A., Bakkali-Kassimi, L.,
Fablet, A., Vitour, D. and Breard, E. (2014) Novel bluetongue virus in goats, Corsica, France, 2014. Emerg. Infect. Dis., 20: 2123-2125.

9. Chand, K., Biswas, S.K., Pandey, A.B., Muthuchelvan, D. and Mondal, B. (2015) Bluetongue in India: A review. $A d v$. Anim. Vet. Sci., 5: 605-612.

10. Rao, P.P., Hegde, N.R., Reddy, Y.N., Krishnajyothi, Y., Reddy, Y.V., Susmitha, B., Gollapalli, S.R., Putty, K. and Reddy, G.H. (2016) Epidemiology of bluetongue in India. Transbound. Emerg. Dis., 63: e151-e164.

11. Maan, S., Maan, N.S., Belaganahalli, M.N., Kumar, A., Batra, K., Rao, P.P., Hemadri, D., Reddy, Y.N., Putty, K., Krishnajyothi, Y., Reddy, G.H., Singh, K.P., Hegde, N.R., Nomikou, K., Sreenivasulu, D. and Mertens, P.P. (2015) Genome sequence of bluetongue virus Type 2 from India: Evidence for reassortment between outer capsid protein genes. Genome Announc., 3(2): e00045-15.

12. Carpi, G., Holmes, E.C. and Kitchen, A. (2010) The evolutionary dynamics of bluetongue virus. J. Mol. Evol., 70: 583-592.

13. Boyle, D.B., Bulach, D.M., Amos-Ritchie, R., Adams, M.M., Walker, P.J. and Weir, R. (2012) Genomic sequences of Australian bluetongue virus prototype serotypes reveal global relationships and possible routes of entry into Australia. J. Virol., 86: 6724-6731.

14. Sreenivasulu, D., Rao, M.V. and Gard, G.P. (1999) Isolation of bluetongue virus serotype 2 from native sheep in India. Vet. Rec., 144: 452-453.

15. Maan, S., Maan, N.S., Ross-Smith, N., Batten, C.A., Shaw, A.E., Anthony, S.J., Samuel, A.R., Darpel, K.E., Veronesi, E., Oura, C.A., Singh, K.P., Nomikou, K., Potgieter, A.C., Attoui, H., van Rooij, E., van Rijn, P., De Clercq, K., Vandenbussche, F., Zientara, S., Breard, E., Sailleau, C., Beer, M., Hoffman, B., Mellor, P.S. and Mertens, P.P. (2008) Sequence analysis of bluetongue virus serotype 8 from the Netherlands 2006 and comparison to other European strains. Virology, 377: 308-318.

16. van Gennip, R.G., van de Water, S.G. and van Rijn, P.A. (2014) Bluetongue virus nonstructural protein NS3/NS3a is not essential for virus replication. PLoS One, 9: e85788.

17. Chauveau, E., Doceul, V., Lara, E., Breard, E., Sailleau, C., Vidalain, P.O., Meurs, E.F., Dabo, S., Schwartz-Cornil, I., Zientara, S. and Vitour, D. (2013) NS3 of bluetongue virus interferes with the induction of Type I interferon. J. Virol., 87: 8241-8246

18. Balasuriya, U.B., Nadler, S.A., Wilson, W.C., Pritchard, L.I., Smythe, A.B., Savini, G., Monaco, F., De Santis, P., Zhang, N., Tabachnick, W.J. and Maclachlan, N.J. (2008) The NS3 proteins of global strains of bluetongue virus evolve into regional topotypes through negative (purifying) selection. Vet. Microbiol., 126: 91-100.

19. Breard, E., Sailleau, C., Nomikou, K., Hamblin, C., Mertens, P.P., Mellor, P.S., El Harrak, M. and Zientara, S. (2007) Molecular epidemiology of bluetongue virus serotype 4 isolated in the Mediterranean Basin between 1979 and 2004. Virus Res., 125: 191-197. 